Kwartalnik Historyczny

Vol. CXXVIII, 2021

Eng.-Language Edition no. 5, pp. 131-166

PL ISSN 0023-5903

MICHAE SIEDZIAKO

https://orcid.org/0000-0003-0799-0222

Departmental office for Historical Research

of the Institute of National Remembrance in Szczecin

Institute of Political Science and Security Studies

of the University of Szczecin

\title{
WERE ELECTIONS IN THE SOCIALIST COUNTRIES ELECTIONS AT ALL? THE CASE OF ELECTIONS TO THE SEJM IN COMMUNIST-RULED POLAND
}

Abstract: The article presents the current state of research into parliamentary elections in Poland during the period of communist rule. The author outlines the development of the electoral system of the Polish People's Republic in the 1940s and 50s, and also analyses its singular features in the years when elections to the Sejm were fully controlled by the ruling Polish United Workers' Party. The final part of the paper is devoted to elections in the 1980s, when this electoral model collapsed, thereby contributing to the disintegration of the communist dictatorship in Poland.

Key w ords: Polish People's Republic, state-controlled elections, undemocratic elections, election fraud, election propaganda, Polish United Workers' Party.

\section{Introduction}

At the outset of this article I feel obliged to provide readers with linguistic clarification. The term 'elections' describes a specific political procedure - namely, the selection of representatives by citizens. However, the very act of choosing assumes that the agent has at least two possibilities at his or her disposal. Indeed, this is a sine qua non. Without it, we cannot speak of any 'choice' or 'elections'.

Poland under communist rule was in many ways an exception when compared to other countries in the Soviet Bloc. This thesis is usually substantiated by pointing to the failure of the authorities to collectivize agriculture, the special role played by the Roman Catholic

${ }^{1}$ In the literature we often come across the term 'elections without choice' or 'choiceless elections'. See, for example, Elections Without Choice, ed. Guy Hermet, Richard Rose and Alain Rouquié, London and Basingstoke, 1978; Jerzy Drygalski and Jacek Kwaśniewski, 'No-Choice Elections', Soviet Studies, 42, 1990, 2, pp. 295-315. 
Church, and the relatively well-organized anti-communist opposition of the second half of the 1970s, further augmented by the phenomenon of 'Solidarity' in 1980. Elections to the Sejm [Parliament] of the People's Republic of Poland corresponded to one of two electoral models typical of the communist states, as described decades ago by Alex Pravda. ${ }^{2}$ Nonetheless, this distinction, based primarily on formal criteria (the regulations stipulated under electoral law), should be treated as altogether conventional. For in practice they guaranteed the same result - the filling of nominally representative bodies with persons selected, verified, and approved by the Party. Thus, elections to the Sejm of the Polish People's Republic may be viewed as an example from which we can draw conclusions about other countries of the former Eastern Bloc.

Over the past few years there has been considerable progress in research into the elections in Poland during the period of communist rule. This has resulted in the publication of a number of books thanks to which we know considerably more than we did even ten years ago. ${ }^{3}$ This progress was made possible first and foremost by studies based on archi-

2 Pravda wrote about 'plebiscitary elections' and 'limited-choice elections'. The former occurred when there was only one candidate running for a seat, and the latter if there were fewer seats to be filled than there were candidates (Alex Pravda, 'Elections in Communist Party States', in Communist Politics: A Reader, ed. Stephen White and Daniel Nelson, Basingstoke and London, 1986, pp. 27-54 (pp.32-45). The most recent research findings concerning elections in Soviet Bloc states are presented in Voting for Hitler and Stalin: Elections under $20^{\text {th }}$ Century Dictatorships, ed. Ralph Jessen and Hedwig Richter, Frankfurt am Main, 2011. See also Elections in Socialist States, ed. Robert K. Furtak, New York, 1990.

${ }^{3}$ See in particular Paulina Codogni, Wybory czerwcowe 1989 r.: U progu przemiany ustrojowej, Warsaw, 2012; Tomasz Danilecki, Między zaangażowaniem, przystosowaniem i sprzeciwem: Postawy mieszkańców województwa białostockiego wobec wyborów powszechnych w latach 1957-1969, Białystok and Warsaw, 2019; Joanna Olejniczak, Wybory do Sejmu i rad narodowych $w$ województwie bydgoskim $w$ okresie tzw. małej stabilizacji (19561970), Toruń, 2010; Zenon Romanow, Demokracja ludowa w praktyce: Wybory do Sejmu i rad narodowych w województwie koszalińskim w latach 1950-1975, Słupsk, 2019; Andrzej Zaćmiński, Kampania wyborcza i wybory do Sejmu PRL I kadencji z 1952 r.: Studium totalitarnej elekcji parlamentarnej, Bydgoszcz, 2020; Wybory i referenda $w$ PRL, ed. Sebastian Ligarski and Michał Siedziako, Szczecin, 2014. I have written a monograph that is an attempt at a synthetic analysis of the problem: Michał Siedziako, Bez wyboru: Głosowania do Sejmu PRL (1952-1989), Warsaw, 2018. A monograph by Robert Skobelski devoted to the elections to the Second Sejm of the Polish People's Republic of January 1957 should be published shortly. These works show that, relatively speaking, elections held during the term of office of Edward Gierek, First Secretary of the Central Committee of the Polish United Workers' Party in the years 1970-80, as well as the only election held according to the socialist model under General Wojciech Jaruzelski in 1985, are the least analysed. I omit here works devoted to the elections to the Legislative Sejm of January 1947, which were in many ways unique and have already been discussed copiously and in detail in the literature. 
val sources, and also through the utilization of oral history, which is still possible for this topic. During my more than ten years of research into the elections to the Sejm of the Polish People's Republic, I made use of the resources of a dozen or so national archives (including the Archives of Modern Records, the Archives of the Chancellery of the President of the Republic of Poland, and the Archives of the Institute of National Remembrance), regional repositories (among others, the State Archives in Szczecin and Lublin), and of the accounts of historical witnesses. Of particular importance were the archival materials generated by the central apparatus of the Polish United Workers' Party and the electoral administration of communist Poland - the State Electoral Commission and its subordinate lower-level commissions (right down to the level of district electoral commissions).

\section{The Development of the Electoral System of the Polish People's Republic}

The first four general elections held following the Soviets' installation of the communist system in Poland can be considered stages in the development of electoral solutions that were then utilized by the communists over a period of more than two decades of comparative stability. ${ }^{4} \mathrm{We}$ are referring here to the so-called people's referendum of June 1946, the elections to the Legislative Sejm of January 1947, and the elections to the First (October 1951) and Second (January 1957) Sejm of the People's Republic of Poland. Although they took place over a comparatively short time span, each was held under very dissimilar conditions, which makes them in many ways unique. But each also introduced mechanisms that went on to become integral to the catalogue of electoral practices of the communist Polish state. Interestingly, many were adopted from the Soviet Union, whose systemic-political solutions constituted a sui generis 'ideal type' that was implemented in the satellite countries, among them post-war Poland. This was done in individual states with, however, a measure of regard for their national specificity. ${ }^{5}$

${ }^{4}$ The stability was only relative, because communist Poland experienced cyclical crises, better known today as the 'Polish months'. With the exception of the elections of January 1957, however, the authorities always avoided holding ballots during periods of crisis, while whenever the political situation required it, elections were brought forward (as in 1972) or postponed (as in 1985). Regarding these crises see Jerzy Eisler, The 'Polish Months': Communist-ruled Poland in Crisis, transl. Jerzy Giebultowski, Warsaw, 2019.

${ }^{5}$ Concerning elections in the Soviet Union see, among others, Stephan Merl, 'Elections in the Soviet Union, 1937-1989: A View into a Paternalistic World from 
The first of the ballots in question - the referendum of 1946 - was conducted in place of the parliamentary elections which the new government in Warsaw (the formally coalitional Provisional Government of National Unity, which, while dominated by the communists and their allies, was the first Polish government backed by Moscow and recognized by the Western Allies) was obliged to hold in accordance with the arrangements agreed by the Yalta Conference of February 1945 organized by the leaders of the anti-Nazi coalition. De facto two political blocs were vying for influence in Poland at the time: one dominated by the communists from the Polish Workers' Party, who were subordinate to Moscow, and the other dominated by democrats, among whom the sole party that was capable of threatening the communists and was still allowed to function in the country was the Polish People's Party headed by Stanisław Mikołajczyk, the former Prime Minister of the Government-in-Exile in London. The leadership of the Polish Workers' Party was well aware that their grouping enjoyed at best limited support within Polish society. Thus, a referendum intended to settle issues of policy that were of subsidiary importance to the main political struggle would, as they saw it, allow them to adequately reconnoitre public feeling and gain time to prepare for the elections proper, which - due to the fact that they were required pursuant to international obligations - were unavoidable. The date of the referendum was set for 30 June 1946.

The three questions in the referendum were phrased in such a way as to ensure that, almost automatically, the most natural response to each, by being concordant with the expectations of the majority of society, was 'yes'. Specifically, they concerned 1) the abolition of the Senate, 2) support for the economic reforms initiated by the communists (through whom, among other matters, the peasants had been granted land), and 3) approval of Poland's post-war territorial gains in the west at the expense of Germany. The communists and their allies (the 'democratic bloc') appealed to the nation to vote 'three times yes'. The largest independent grouping - Mikołajczyk's Polish People's Party - saw the need to differentiate itself; it therefore opposed abolition of the bicameral parliament, even though before the War this had been an important postulate of the peasants' movement. ${ }^{6}$ The Christian Democratic Labour Faction - an-

Below', in Voting for Hitler and Stalin, pp. 276-308; Theodore H. Friedgut, Political Participation in the USSR, Princeton, NJ, 1979; Max E. Mote, Soviet Local and Republic Elections: A Description of the 1963 Elections in Leningrad Based on Official Documents, Press Accounts, and Private Interviews, Stanford, CA, 1965.

${ }^{6}$ Czesław Osękowski, Referendum 30 czerwca 1946 roku w Polsce, Warsaw, 2000, pp. 32 , 85-86; Krystyna Kersten, Narodziny systemu władzy: Polska 1943-1948, Warsaw, 2018, p. 310. 
other legally functioning party, although much smaller than the People's Party, also called upon electors not to vote in accordance with communists demands, as did other national groupings - including the post-Home Army organizations that were active in the underground following the dissolution in January 1945 of the clandestine Home Army, which was subordinate to the legal Government-in-Exile in London.?

The campaign which preceded the referendum was dominated in its entirety by the communists, who made use of both the Party apparatus and state institutions (which they fully controlled), among them the public security apparatus, which at the time was receiving significant support from Soviet military units. ${ }^{8}$ Varied and very large-scale propaganda activities were intermixed with a host of repressive measures aimed against political opponents. One of the most important issues in this context was the struggle against the armed underground, whose members vehemently opposed Poland's subordination to the Soviet Union. But arrests, beatings, confiscations of property, dismissals from work, and even political murders also targeted the legal opposition to the Polish Workers' Party (PPR), with activists of the Polish People's Party (PSL) bearing the brunt of these measures.

The results of the referendum were falsified with the assistance of a group of officers delegated to Poland from the Soviet Ministry of State Security, who were commanded by Colonel Aron Palkin and specialized in the forging of documents. ${ }^{9}$ The scale of discrepancies between data announced by the government and the actual results of the ballot was huge. Information on the matter was sent directly to the head of the PPR, Bolesław Bierut; the pertinent documents were found and published following the collapse of the Polish People's Republic by the historian Andrzej Paczkowski. According to official figures, the turnout was $90.1 \%$, with the answer 'yes' being given to individual questions as follows: to the first - by $7,844,522$ (66.15\%) voters, to the second - by 8,896,105 (75.02\%), and to the third by $10,534,697$ ( $88.84 \%)$. But while more than $90 \%$ of eligible voters did indeed take part, the positive responses to individual questions were $26.9 \%$, $42 \%$ and $66.9 \%$, respectively. ${ }^{10}$

${ }^{7}$ Osękowski, Referendum, pp. 93, 97.

${ }^{8}$ For additional information see Grzegorz Motyka, Na białych Polaków obława: Wojska NKWD $w$ walce z polskim podziemiem 1944-1953, Cracow, 2014.

${ }^{9}$ See Nikita Petrov, 'Sztuka wygrywania wyborów', Karta, 18, 1996, pp. 121-29.

${ }^{10}$ Referendum z 30 czerwca 1946 r.: Przebieg i wyniki, ed. Andrzej Paczkowski, Warsaw, 1993, pp.159, 161; 'Ogłoszenie Generalnego Komisarza Głosowania Ludowego o wyniku głosowania ludowego z dnia 30 czerwca 1946 r.', Monitor Polski, 12 July 1946, no. 61, item 115. 
After the referendum, the opponents of communist rule in Poland were so thoroughly weakened - and the new state apparatus so well-trained that the leaders of the Polish Workers' Party decided to hold elections to the Legislative Sejm in January 1947. During the electoral campaign use was again made of a plethora of propaganda activities, while repression against the opposition was intensified. The influence of the Polish People's Party was also combated via administrative means. The electoral apparatus, which was staffed with trusted functionaries: according to data of the Ministry of Public Security, local security offices recruited nearly one half of the membership of regional and district electoral commissions as agents made it difficult for Mikołajczyk's party to register lists of candidates for Members of Parliament. Indeed, in ten electoral regions its lists were invalidated altogether. Thus, more than five million voters (approx. $22 \%$ of the country's then population) were deprived of the possibility to cast their ballots for the Polish People's Party. ${ }^{11}$

Once again, the results were falsified. In contrast to the fraud committed during the referendum, this time the documentation was fabricated by Poles themselves. Moreover, the practice was much better camouflaged than before. The actual election results for the whole country remain unknown to this day, and have been determined only for a few districts. ${ }^{12}$ According to the official proclamation of the result, $89.9 \%$ of those eligible took part, of whom $80.1 \%$ cast their votes for the list of the 'democratic bloc', 10.3\% for the Polish People's Party, 4.7\% for the Labour Faction, 1.4\% for the Catholic groupings advocating co-operation with the communists, and 3.5\% for the Polish People's Party 'Nowe Wyzwolenie' [New Liberation], which was directly controlled by the communists. ${ }^{13}$ Thus, while operating under formal conditions of pluralism, the communists secured themselves complete dominance.

Activists of the Polish People's Party tried to challenge the results, with Mikołajczyk claiming that his party had in fact received the support of $60-70 \%$ of voters. ${ }^{14}$ These estimates were over-optimistic. Colonel Palkin was again present in Poland, though he was held in reserve, so to speak:

${ }^{11}$ Janusz Wrona, 'Wstęp', in Kampania wyborcza i wybory do Sejmu Ustawodawczego 19 stycznia 1947, ed. idem, Warsaw, 1999, p. 29; Czesław Osękowski, Wybory do sejmu 19 stycznia 1947 roku w Polsce, Poznań, 2000, pp. 66-67.

${ }_{12}$ The most recent findings regarding the issue have been presented in a study by Kamila Churska-Wołoszczak, which, however, concerns only one province in the formerly German lands acquired by Poland after the War; these territories were in many ways unique. See Kamila Churska-Wołoszczak, Referendum ludowe i wybory do Sejmu Ustawodawczego w województwie pomorskim (1946-1947), Bydgoszcz and Gdańsk, 2014, pp. 236-40.

${ }^{13}$ Wrona, 'Wstęp', pp. 40-41.

${ }^{14}$ Ibid. 
this time the fraud was organized by the Polish Security Service, which acquitted itself so well that the assistance of Palkin's group was not required. Palkin authored a report for Stalin claiming that approximately $50 \%$ of voters had actually opted for the 'democratic bloc', even more in rural areas. ${ }^{15}$ All of the election protests lodged by the Polish People's Party were rejected out of hand. Soon, Mikołajczyk, threatened with arrest on trumped up charges, was forced to leave Poland, never to return.

The way in which the referendum and the elections to the Legislative Sejm were conducted clearly showed that the communists had no consideration for the actual opinions of citizens, but were focused solely on gaining complete power. The elections were intended first and foremost to sanction their authority by creating the appearance of legality, and at once satisfy international obligations, obviously in a completely twisted manner. Both ballots already contained certain elements that were characteristic of the Soviet electoral system, although they differed from the model - primarily because both had included political forces opposed to the communists. We can, however, compare them with the Soviet elections of the 1920s, when the Bolsheviks led a brutal struggle to strengthen their authority. ${ }^{16}$ The salient aspects were as follows: pressuring voters to resign from their right to vote in secrecy, the recognition of blank election cards as valid votes cast in favour of solutions favoured by the authorities (such had also been the case with blank voting cards in the referendum), an insistence on achieving the highest possible turnout, the top-down, administrative limitation of the choices open to voters through the elimination of lists of candidates independent of the authorities, exercising maximum control over the electoral apparatus, and - last but not least - the instrumentalization of elections by depriving them of their primary role as a means through which citizens can decide about the shape of their representative authorities by choosing between candidates from various political groupings. Elections were to become a staged show of support for the ruling party.

It is worth noting that also in other countries of Central and Eastern Europe which after the Second World War found themselves in the Soviet sphere of influence - Hungary, Bulgaria, and Romania - rigged elections accompanied by a wave of terror against the political opposition were an important stage on the road to the assumption of complete power by the communist groupings subordinate to Moscow. ${ }^{17}$ The situation developed

\footnotetext{
${ }^{15}$ Petrov, 'Sztuka', p. 129.

${ }^{16}$ Pravda, 'Elections', p. 29.

${ }^{17}$ Siedziako, Bez wyboru, pp. 37-41. For additional information see, among others,
} 
somewhat differently in Czechoslovakia, where the communists actually had broader support that translated into a genuine electoral victory in May 1946. Nevertheless, the Communist Party of Czechoslovakia was unable to gain a monopoly of power and therefore opted to crush the opposition so that the elections of 1948 could be organized fully in accordance with its dictate. ${ }^{18}$ Also distinct was the creation of the communist East German state - the German Democratic Republic, which was established in the former Soviet occupation zone. There, too, communist authority was legitimized through parliamentary elections that were organized and controlled by the Party. ${ }^{19}$

In Poland, the next parliamentary elections were held under different political conditions. Namely, following the complete elimination of all opposition to the regime and the total domination of the Polish political scene by the communists, who, following the absorption of the Polish Socialist Party by the Polish Workers' Party in December 1948, created the Polish United Workers' Party (PZPR being the Polish acronym), which ruled the country with absolute power for the next forty-one years. Although two other groupings continued to function legally (the United People's Party and the Alliance of Democrats), multi-partyism was only formal. In reality, these two parties were totally controlled by the PZPR, whose leaders decided both their budgets and the staffing of their executive committees. Towards the end of its existence, the Legislative Sejm adopted a new constitution that sanctioned the systemic transformation brought about at the dictate of Moscow. This constitution also formally introduced the new name of the state (the Polish People's Republic), and made the Sejm the central body of state authority.

The elections to the First Sejm of the Polish People's Republic of October 1952 exemplified the advanced Sovietization of the country. ${ }^{20}$ Indeed,

Zoltan D. Barany, 'Elections in Hungary', in Elections in Socialist States, pp. 71-97; Adam Koseski, 'Walka o władzę w Bułgarii', in Czy Europa Środkowo-Wschodnia mogła wybić się na wolność?, ed. Tadeusz Kisielewski and Norbert Kasparek, Olsztyn, 1996, pp. 123-45; Dinu C. Giurescu, Fakers: The 1946 Elections, transl. Adriana Cerkez, Boulder, CO, 2009.

${ }^{18}$ Tomáš Lebeda, 'Czech Republic', in Elections in Europe: A Data Handbook, ed. Dieter Nohlen and Philip Stöver, Baden-Baden, 2010, pp. 453-500 (pp. 456-57). For additional information see Peter Heumos, 'Works Council Elections in Czechoslovakia, 1948-1968', in Voting for Hitler and Stalin, pp. 186-203.

${ }^{19}$ Ralf Lindner and Rainer-Olaf Schultze, 'Germany', in Elections in Europe, pp. 723-806 (p. 731); Gert-Joachim Glaessner, 'Elections in the German Democratic Republic', in Elections in Socialist States, pp. 53-70 (p. 54). For additional information see Hedwig Richter, 'Mass Obedience: Practices and Functions of Elections in the German Democratic Republic', in Voting for Hitler and Stalin, pp. 103-25.

${ }^{20}$ For additional information see Michał Siedziako, 'Przygotowanie wyborów do Sejmu PRL I kadencji w 1952 roku jako element procesu sowietyzacji Polski po 
no other elections held in Poland during the period of communist rule were as close to the Soviet 'ideal'. The leadership of the PZPR made use of the Soviet blueprint when drawing up the new electoral statute, the technical details of which were modelled after the law adopted for the elections to the Supreme Soviet of the USSR of $1950 .{ }^{21}$ The one major difference concerned the number of deputies elected in individual regions - in the Soviet Union, electoral regions were single-mandate, while in Poland a few deputies were to be chosen in each. In practice, however, the result was the same, for it was assumed beforehand that only one candidate would be put up for each seat. ${ }^{22}$ In order not to allow the registration of additional candidates - an option provided for by law - the Party apparatus together with the Public Security Service carefully controlled the composition of electoral commissions, which (at the regional level) were tasked with registering electoral lists; only activists who were 'politically reliable' and 'experienced' could become their members. ${ }^{23}$

All candidates ran for office under the aegis of the Electoral Commission of the National Front, which formally grouped various, seemingly disparate, organizations (its composition was approved by the highest echelons of the PZPR) ${ }^{24}$ Initially, a few candidates were registered for each seat; among them would be party leaders, and, necessarily, the one 'appropriate' candidate. The leaders could withdraw their candidatures from all regions except one, to which each was himself assigned as the 'appropriate' candidate. ${ }^{25}$ On the one hand, this manipulation created the impression that there were more candidates than was actually the case, while on the other

II wojnie światowej', Zeszyty Naukowe Uniwersytetu Jagiellońskiego. Prace Historyczne, 144, 2017, 4, pp. 739-58.

${ }^{21}$ Notatka do projektu ordynacji wyborczej, undated document [1952], AAN (Archives of Modern Records), Warsaw, Komitet Centralny Polskiej Zjednoczonej Partii Robotniczej (Central Committee of the Polish United Workers' Party) (hereinafter KC PZPR), V/21, unpaginated file.

${ }^{22}$ This was achieved by combining specific provisions of the electoral statute with concrete, practical steps. Formally, the statute allowed the registration of many electoral lists in each region, however each list could only contain a number of candidates corresponding to the number of seats in a given region. Furthermore, it was assumed in advance that only one electoral list would be registered in each region. For additional information on the covering-up of undemocratic electoral practices with seemingly democratic legislation in Poland under communist rule see Wojciech Sokół, 'Systemy wyborcze w Polsce Ludowej - uwarunkowania, mechanizmy i konsekwencje polityczne', in Wybory i referenda w PRL, pp. 23-44.

${ }^{23}$ Notatka w sprawie organizacji wyborów do Sejmu, 26 July 1952, AAN, KC PZPR, V/23, p. 60.

${ }^{24}$ Protokół $\mathrm{nr} 187 \mathrm{z}$ posiedzenia Sekretariatu Biura Organizacyjnego Komitetu Centralnego PZPR, 14 August 1952, AAN, KC PZPR, V/17, unpaginated file.

${ }^{25}$ Notatka do projektu, undated document [1952], AAN, KC PZPR, V/21. 
it bolstered the propagandistic thesis that there was widespread support for the party leadership, which purportedly everyone wanted to have in parliament. The same manoeuvre was regularly used during elections in the Soviet Union. ${ }^{26}$

Soviet models were also utilized in election propaganda, which contained strong anti-American accents and juxtaposed the idyllic image of countries from the socialist bloc with the dark reality of the capitalist states of the West, accusing them of fomenting a global conflict, limiting the freedom of citizens, and exploiting the working class. ${ }^{27}$ Interestingly, propaganda actions were comprehensive in nature; use was made of both typical promotional tools, including posters and leaflets, rallies and meetings between voters and candidates, and press articles and radio broadcasts, and forms that were seemingly not associated with politics artistic events, sports competitions - but which were accompanied by electoral agitation. ${ }^{28}$ Some authors even wrote agitational poetry. ${ }^{29}$ Following the example of the Soviet Union, an enormous number of agitators were mobilized for the electoral campaign - more than 800,000 (although some sources claim they numbered in excess of one million) whose role was to reach every voter, with each activist being responsible for a few houses or one apartment block, on average 10-15 families. ${ }^{30}$ The campaign was 'secured' by functionaries of the Public Security Service, whose task was to track down and counter all manifestations of critique of the elections or the existing socio-political order. Of key importance in this regard was the intensification of repression, which took on

${ }^{26}$ Georg Brunner, 'Elections in the Soviet Union', in Elections in Socialist States, pp. 20-52 (pp. 34-35).

${ }^{27}$ Electoral Programme of the National Front, 1952, AAN, Biuro Ogólnopolskiego Komitetu Frontu Narodowego (Office of the All-Polish Committee of the National Front) (hereinafter BOKFN), 8, unpaginated file; Electoral materials of the National Front (posters, leaflets, brochures), 1952, AAN, Elections to the Sejm of 1952 - a collection of files, 388/1-6. For additional information see, among others, Jacek Wojsław, 'Kampania propagandowa towarzysząca wyborom do Sejmu z 26 października 1952 roku', Polska 1944/45-1989: Studia i Materiaty, 9, 2010, pp. 133-53.

${ }^{28}$ Biuletyn Informacyjny $\mathrm{Nr} 1$ (na podstawie sprawozdań Wojewódzkich Komitetów Wyborczych Frontu Narodowego), 21 October 1952, AAN, BOKFN, 8, unpaginated file; Sprawozdanie z wyborów Wojewódzkiego Komitetu Frontu Narodowego w Katowicach, 7 November 1952, AAN, BOKFN, 14, unpaginated file.

${ }^{29}$ For additional information see Andrzej Zaćmiński, 'Poezja agitacyjna w kampanii wyborczej do Sejmu PRL pierwszej kadencji z 26 października 1952 r.: Tematyka Obrazowanie - Polityka',DN, 50, 2018, 2, pp.181-214.

${ }^{30}$ Instrukcja w sprawie zadań organizacji partyjnych w kampanii wyborczej do Sejmu, 1 September 1952, AAN, KC PZPR, V/23, p. 254; Marcin Zaremba, Komunizm, legitymizacja, nacjonalizm: Nacjonalistyczna legitymizacja władzy komunistycznej $w$ Polsce, Warsaw, 2005, p. 203; Zaćmiński, Kampania, pp. 159-60. 
a multitude of forms: arrests, 48-hour detainments, interrogations, 'cautionary' talking-tos, forcing people to sign declarations of loyalty to the authorities, and recruiting others as agents. In the period immediately preceding the elections these forms affected at least 30,000 citizens according to statistics of the Ministry of Public Security. ${ }^{31}$

According to official data, the ballot of 26 October 1952 was cast by 95.03\% of eligible voters, the overwhelming majority of whom (99.8\%) gave their support to candidates of the National Front, who were the only ones standing for election. In order to do this - to give one's support - it was deemed sufficient to put the card containing the list of candidates, which one received from the district electoral commission, into the ballot box. Such votes 'without crossings-out' (encouraged by government propaganda) were allocated to the list as a whole. Archival research has shown that, yet again, the results were doctored by the application of electoral fraud. ${ }^{32}$ This is made plain by the extant documentation of district electoral commissions. Perhaps the practice most frequently used to improve turnout figures involved striking out those who did not take part in the ballot from the lists of eligible voters. ${ }^{33}$ Furthermore, invalid votes were commonly reclassified as valid. ${ }^{34}$ Voting reports from a great many district electoral commissions contain annotations made by members of the election staff which indicate that voters were pressurized. ${ }^{35}$

${ }^{31}$ Zestawienie aresztowanych według województw, undated document [October 1952], AIPN (Archive of the Institute of National Remembrance), Warsaw, BU 00231/86, vol. 91, p. 601; Inne środki represji stosowane w związku z ochroną wyborów w okresie od 1 października do dnia wyborów włącznie, undated document [October 1952], AIPN, BU 00231/86, vol. 91, p. 600.

${ }^{32}$ For additional information see Michał Siedziako, 'Manipulacje i fałszerstwa wyborcze w wyborach do Sejmu PRL (1952-1985)', Pamięć i Sprawiedliwość, 27, 2016, 1, pp. 112-39 (pp. 116-23).

${ }^{33}$ Protokół głosowania sporządzony przez Obwodową Komisję Wyborczą nr 232 w okręgu wyborczym nr 1, 27 October 1952, AAN, Państwowa Komisja Wyborcza (State Electoral Commission) (hereinafter PKW), 99, p. 464; Protokół głosowania sporządzony przez Obwodową Komisję Wyborczą nr 69 w okręgu wyborczym nr 8, 26 October 1952, AAN, PKW, 106, p. 142; Protokół głosowania sporządzony przez Obwodową Komisję Wyborczą nr 23 w okręgu wyborczym nr 40, AAN, PKW, 26 October 1952, AAN, PKW, 138, p. 49.

${ }^{34}$ Protokół głosowania sporządzony przez Obwodową Komisję Wyborczą nr 5 w okręgu wyborczym nr 17, 26 October 1952, AAN, PWK, 115, p. 12; Protokół głosowania sporządzony przez Obwodową Komisję Wyborczą nr 185 w okręgu wyborczym nr 36, 26 October 1952, AAN, PKW, 134, p. 378; Protokół głosowania sporządzony przez Obwodową Komisję Wyborczą nr 27 w okręgu wyborczym nr 44,26 October 1952, AAN, PKW,142, p. 56.

${ }^{35}$ Protokół głosowania sporządzony przez Obwodową Komisję Wyborczą nr 15 w okręgu wyborczym nr 17, 26 October 1952, AAN, PKW, 115, p.33; Protokół głosowania sporządzony przez Obwodową Komisję Wyborczą nr 113 w okręgu wyborczym nr 36, 26 October 
The practices described above allowed the communists to determine the composition of parliament long before the elections actually took place. All the candidates from National Front lists obtained parliamentary seats. Thus, the leadership of the PZPR assured itself complete control over the make-up of the Polish Sejm. In consequence, parliament could not function as an independent centre of political decision-making, although such was its role according to the constitution. In the political system of the Polish People's Republic, this capacity was reserved for the PZPR, the Polish United Workers' Party.

The development of the electoral system of the Polish People's Republic came to an end with the elections to the Sejm of 1957. These took place under conditions of the crisis brought about by the decomposition of the Stalinist totalitarian model in Poland following the death of Joseph Stalin in March 1953. The process was affected by two groups of factors. On the one hand, there was a reshuffle among the highest echelons of authority in the wake of the broad disclosure of the illegal activities undertaken by the public security apparatus over the previous years. This was precipitated by the defection to the West of Lieutenant Colonel Józef Światło, a high-ranking officer of the Security Service, in the autumn of 1953, and the death in March 1956 of the First Secretary of the Central Committee of the Polish United Workers' Party, Bolesław Bierut. Soon - and this element was of equally great importance many people read or were informed, of course unofficially, about the existence of Nikita Khrushchev's secret speech, in which he subjected the Stalinist model of government to a fundamental critique. On the other hand, the transformation which was commenced in Poland was to some extent a reaction to the grass-roots pressure of the citizens at large, who were calling for the liberalization of the oppressive regime. One of the most common demands was for a democratization of the electoral law that would allow the people to actually choose their parliamentary representatives. ${ }^{36}$ Some attempt was made to accommodate these expectations, particularly as the Party was now headed by the new First Secretary of its Central Committee, Władysław Gomułka, who previously, in the years 1943-48, had led the Polish Workers' Party but who had been removed from power after being accused of 'right-wing nationalist deviationism'. As a former Stalinist prisoner, he became the

1952, AAN, PKW, 134, p. 233; Protokół głosowania sporządzony przez Obwodową Komisję Wyborczą nr 118 w okręgu wyborczym nr 51, 26 October 1952, AAN, PKW, 149, p. 235.

${ }^{36}$ For additional information see Paweł Machcewicz, Rebellious Satellite: Poland 1956, transl. Maya Latynski, Washington, DC, and Stanford, CA, 2009. 
symbol of the 'Thaw', as this period is known, and enjoyed immense, authentic public support. The electoral statute was modified by the introduction of a provision whereby each electoral list would contain a number of candidates exceeding that of the vacant seats. Furthermore, the National Front, which was very much associated with the former period, was liquidated. Gomułka announced that voters would actually be able to 'choose' - not only to 'vote' - and that only persons enjoying actual public support would become Members of Parliament. 'He who does not command the broad trust of voters shall not, quite obviously, take a seat in the future Sejm', he declared. ${ }^{37}$

Although perforce respectful of the wave of animation which overtook the country in the wake of the Thaw, the Party was quick to implement measures that would ensure it would not lose its grip on parliament. First of all, the National Front was replaced with a new common electoral platform of the communists and all other officially recognized groupings and organizations: the Front of National Unity (FJN being the Polish acronym). Now it became the role of the FJN - controlled by the Party in the same way as its predecessor - to endorse all electoral lists. Since, however, the authorities continued to adhere to the principle that only a single list would be registered in each electoral region, and yet made the concession that the number of candidates would exceed the number of seats, the selection of candidates and the order in which they were placed on lists gained paramount importance. Once again it was assumed that votes 'without crossings-out' would be valid and allocated to candidates on a given list in proportion to the number of seats in a given region. Thus, for example, if in a region with three parliamentary seats the FJN electoral list had five names, a vote cast without crossing-out any name on the list (every voter was entitled to cross out names - therein consisted the choice promised by Gomulka) was treated as one cast for candidates occupying positions 1-3 - that is, those which guaranteed membership of the Sejm. Accordingly, these candidates became the main object of interest of the Party authorities. At the same time, it was decided not to interfere with the grass-roots registration of nominees who enjoyed considerable support in local communities, this being seen as a way of diffusing social tensions. ${ }^{38}$ Nonetheless, the submission of electoral lists independent of the authorities (that is, ones not endorsed by the FJN) was

${ }^{37}$ Quoted from: Paweł Machcewicz, 'Wstęp', in Kampania wyborcza i wybory do Sejmu 20 stycznia 1957, ed. idem, Warsaw, 2000, p. 8.

${ }^{38}$ For additional information see Robert Skobelski, 'Controversies Surrounding the Selection of Candidates for MPs Before the Election to the PRL Sejm of January 1957', Res Historica, 49, 2020, pp. 425-64. 
blocked by the electoral commissions, which, as previously, were staffed with trusted functionaries. ${ }^{39} \mathrm{Just}$ as in 1952 , the public security apparatus, now somewhat reorganized, was tasked with 'securing' the elections and countering any and all opposition to the authorities. However, under the conditions of the Thaw its activity was sharply curtailed - repression no longer targeted the broad masses of society, but rather individuals whose attitudes and behaviour were considered exceptionally radical. ${ }^{40}$

The campaign that preceded the elections planned for January 1957 was unique in the entire history of the People's Republic of Poland. ${ }^{41}$ In some instances, the political tussles between candidates - now vying for a smaller number of seats - were indeed vociferous and heated. On the last stretch of the campaign, however, the Party authorities, fearing that this element of spontaneity would lead to the new Sejm being made up at least in part of persons elected from places on FJN lists that were not guaranteed a seat and who could therefore not be controlled by the PZPR, decided to block the process altogether. All voters who supported Gomulka himself and the transformation taking place in the country were summoned to vote openly, 'without crossings-out', and therefore for candidates occupying places guaranteeing seats, that is, who were naturally preferred by the Party leadership. The writer Maria Dąbrowska made the following comment in her private journal: 'Can we start building a lawful democracy by breaking its back? For this is what Gomułka has assuredly done by his abrupt elimination of voting secrecy and freedom of choice - the latter limited but nevertheless to some degree extant'. ${ }^{42}$ Her observation conveys the public feeling of the time.

This method of channelling social activity and the spontaneous, grass-roots rivalry of circles supporting different candidates was one of the first symptoms of the end of the Thaw and the stabilization of the communist system of government in Poland in its liberalized, post-Stalinist version. The elections of January 1957 were rounded off by the utilization of various types of illegal mechanisms aimed at pressuring voters during ballot-

${ }^{39}$ Sprawozdanie Państwowej Komisji Wyborczej z wyborów do Sejmu Polskiej Rzeczypospolitej Ludowej przeprowadzonych dnia 20 stycznia 1957 r., undated document, AAN, PKW, 307, p. 196; Notatka Państwowej Komisji Wyborczej w sprawie rejestracji list kandydatów na posłów, 24 December 1956, in Kampania wyborcza i wybory do Sejmu 20 stycznia 1957, pp. 50-52.

${ }^{40}$ Sprawozdanie z działalności organów MSW w okresie wyborów do Sejmu, 30 January 1957, AIPN, BU 01355/85, vol. 110, p. 265.

${ }^{41}$ Robert Skobelski, 'Ostatnia odsłona odwilży: Kampania przed wyborami do Sejmu PRL ze stycznia 1957 roku', Pamięć i Sprawiedliwość, 35, 2020, 1, pp. 402-35.

${ }^{42}$ Maria Dąbrowska, Dzienniki: 1914-1965, 13 vols, Warsaw, 2009, vol. 10, p. 157. 
ing (preventing them from using curtains so that they could not vote in secrecy, party activists visiting the houses of persons who had of their own volition not voted until a certain hour), and of fraud, intended first and foremost to improve the turnout. Although in light of the actual and immense social enthusiasm which engulfed the entire country these actions did not have to be undertaken on a mass scale, they were nevertheless implemented - as annotations made in electoral documentation show. ${ }^{43}$

While the elections to the Second Sejm of the Polish People's Republic differed from all other parliamentary elections held in Poland under communist rule for the reasons outlined above, the electoral system that was then utilized, understood as a body of legal provisions regulating the conduct of elections and practical rules of action not incorporated in the law, was copied for the next two decades, assuring the PZPR complete control over the composition of the Sejm. This model matured as the result of a telltale evolution that harnessed solutions tested in 1946,1947,1952, and 1957. Interestingly, the example of the elections of January 1957 showed that under this system voters were able - even if only as an exception to reject a candidate imposed by the authorities. The example in question is that of Jan Antoniszczak, a candidate of the PZPR who was not elected to the Second Sejm despite holding a 'guaranteed' place on the electoral list registered in Nowy Sącz. ${ }^{44}$ In successive years, elections were always organized during stable periods of the system of power, when the Party was in control of public sentiment, and thus such an occurrence never repeated itself. Until 1985, all of the candidates whose placement on electoral lists guaranteed election were in fact elected.

\section{The Stabilization of the Electoral System of the Polish People's Republic}

The solutions mentioned above, which were characteristic of the electoral system of the Polish People's Republic and made certain that the PZPR would always decisively influence the composition of parliament, included primarily the following: 1) control over the electoral apparatus, and specifically over electoral commissions at different levels: from the central - the State Electoral Commission - through regional commissions to the district, which had direct contact with voters on voting day; 2) ensuring that

${ }^{43}$ See Siedziako, Bez wyboru, pp. 190-92.

${ }^{44}$ Tomasz Popiela, 'Nowy Sącz w latach eksperymentu sądeckiego 1958-1964', unpublished MA thesis, Jagiellonian University, 2014. 
only 'appropriate' persons were selected as candidates for Members of Parliament, which underscores the importance of the 'guaranteed' places on lists; 3 ) the involvement of all officially recognized organizations and the state-controlled media in election campaigns so as to bring a unified body of propaganda to bear on citizens; 4) the application of pressure at various levels in order to force voters to act in accordance with the expectations of the authorities: participation in the ballot - ensuring the highest possible turnout, voting openly and without crossings-out; and 5) the falsifying of electoral documentation. We should, however, keep in mind that despite these undemocratic practices, the electoral law of the Polish People's Republic satisfied democratic standards up until 1976, when the Front of National Unity (FJN) was entered into the constitution and the electoral statute. From that year on, the principle of only one electoral list being registered under the aegis of the FJN in each region and in every election gained legal sanction. And yet previously the situation had been the same, with the practice being widespread but informal in the sense that, under the electoral law, regional electoral commissions could register many competing lists. The change was therefore cosmetic; it made it easier, however, for the authorities to reject independent electoral lists in successive ballots.

The situation was identical in other European countries of the Soviet Bloc: all candidates in each and every election ran for office under the aegis of a joint electoral bloc, formally coalitional but in fact controlled by the communists. In Bulgaria this was the Patriotic Front; in Czechoslovakia and the German Democratic Republic, the National Front; in Hungary, the Hungarian National Front; while in Romania, the Democratic People's Front/ Front of Socialist Unity/Front of Socialist and Democratic Unity. ${ }^{45}$ In the Soviet Union, however, where not even formal multi-partyism existed, candidates for council delegates at various levels were endorsed by the Block of Communists and the Politically Non-Aligned. ${ }^{46}$

Among the key features of elections in the Polish People's Republic which we have mentioned above, control over electoral commissions was

${ }^{45}$ Elections in Europe: A Data Handbook, ed. Dieter Nohlen and Philip Stöver, Baden-Baden, 2010, pp. 386-87, 457, 779, 922-23, 1612. For additional information on national/ peoples' fronts in various European communist states see, for example, Paweł Skorut, Front Jedności Narodu: Od narodzin idei do upadku politycznego pozoru, Cracow, 2015 (in addition to a presentation of the Polish Front of National Unity, in Chapter 2 of the cited work the author also provides brief descriptions of Fronts in Bulgaria, Czechoslovakia and Hungary); Problemy frontu narodowego w europejskich państwach socjalistycznych, ed. Marian Rybicki, Wrocław, 1973; Barbara Zawadzka, Model przedstawicielstwa socjalistycznego: Studium porównawcze z teorii reprezentacji, Wrocław, 1980.

${ }^{46}$ Tadeusz Szymczak, Ustrój europejskich państw socjalistycznych, Warsaw, 1988, p. 31. 
of paramount importance. This was simply because these bodies were charged with organizing the entire election process and therefore carried out such fundamental tasks as registering candidate lists, counting votes, investigating electoral complaints, and announcing results. Formally, their members were appointed by the Council of State (the State Electoral Commission) and the Presidia of People's Territorial Councils (regional/provincial and district commissions), however the pertinent decisions were always taken by the PZPR. The planned composition of each electoral commission, containing a description of the proposed membership, was submitted by the Chancellery of the Council of State and the Presidia of People's Territorial Councils to the competent unit of the PZPR, the executive of the party committee at the relevant level. Decisions concerning the State Electoral Commission and regional/provincial commissions were taken by the Organizational Department of the Central Committee of the Polish United Workers' Party, while the make-up of district commissions was decided after consultation with local party bodies. ${ }^{47}$ Of key significance were the positions of commission chairman and secretary, which as a rule were to be occupied by trusted activists of the PZPR. ${ }^{48}$ Appropriately staffed, such a commission ensured that the Party had complete control over its activities. This was particularly important in the event of attempts at registering independent electoral lists, the registration of which fell within the competence of regional commissions. All such submissions made in various years were rejected. ${ }^{49}$

${ }^{47}$ See, for example, Proponowane przez prezydia wojewódzkich rad narodowych składy wojewódzkich (miejskich w m. wyłączonych z woj.) komisji wyborczych, 1961, AAN, PKW, 399; Notatka dla Szefa Kancelarii Rady Państwa, 21 February 1969, Archiwum Kancelarii Prezydenta Rzeczypospolitej Polskiej (Archive of the Chancellery of the President of the Republic of Poland) (hereinafter AKPRP), Warsaw, Kancelaria Rady Państwa (Chancellery of the Council of State) (hereinafter KRP), file without signature titled: 'Składy komisji wyborczych: korespondencja z KC PZPR, pisma o powołaniu poszczególnych osób w skład komisji wyborczych, 1969', unpaginated; Proponowany skład Wojewódzkiej Komisji Wyborczej w wyborach do Sejmu i rad narodowych, undated document [1961], AP, Lublin (State Archives in Lublin), Komitet Wojewódzki Polskiej Zjednoczonej Partii Robotniczej (Provincial Committee of the Polish United Workers' Party) (hereinafter KW PZPR), 1702, pp.3-5.

${ }^{48}$ Pismo I zastępcy kierownika Wydziału Organizacyjnego KC PZPR Krystyna Dąbrowy do pierwszych sekretarzy komitetów wojewódzkich PZPR, 8 January 1976, AKPRP, KRP, file without signature titled: 'Zbiór zarządzeń, wytycznych Rady Państwa, Państwowej Komisji Wyborczej, pisma okólne Kancelarii Rady Państwa, 1976, teczka 1', unpaginated.

${ }^{49}$ Odwołanie Zjednoczenia Służb Sprawiedliwości Społecznej od decyzji Okręgowej Komisji Wyborczej w Krakowie, 14 March 1961, AAN, PKW, 400, p. 116; List przewodniczącego Rady Politycznej Konfederacji Polski Niepodległej Leszka Moczulskiego do 
Once it was made certain that only one electoral list of the FJN would be registered in every region in each election, the Party authorities would populate the lists in such a way as to decide who would be elected to the Sejm. And since it was the rule that there were more candidates on a list than seats to be filled, this was achieved by the appropriate selection of persons for so-called guaranteed places, whereafter voters were pressured in order to ensure that these candidates would be 'chosen'. All candidates were selected according to the political key, which determined the division of seats in the Sejm between individual groupings and organizations, and the socio-political key, which specified the number of seats that were to be taken by men and women, the representatives of various professional and age groups, and so on, both of which were determined by the Party leadership.

In the 1960s, candidates for Members of Parliament running from the PZPR were put forward at specially convened Party conferences. In reality, however, in accordance with a secret instruction, lists of candidates in individual regions were written by provincial committees acting in collaboration with the Central Committee of the PZPR, within which the appropriate composition of electoral lists was always overseen. Later, in the 1970s, this function was carried out by a specially-appointed commission..$^{50}$ The lists had to contain a specific number of representatives of various social and professional groups, which followed from the assumption that the make-up of the Sejm of the Polish People's Republic must reflect the social and professional structure of society, thereby confirming its 'democratism'. ${ }^{51}$ Candidacies arranged and approved by Party bodies would then be put forward at the aforementioned conferences, during which delegates representing the totality of Party members could propose additional candidates. As a rule, however, such nominees received only 'non-guaranteed' places on lists. Before being passed on to committees of the FJN, candidate lists officially put forward at regional party conferences were subjected to final

przewodniczącego Państwowej Komisji Wyborczej, undated document [March 1980], AKPRP, KRP, file without signature titled: 'Skargi i wnioski związane z wyborami do Sejmu PRL i rad narodowych st. wojewódzkiego, 1980', unpaginated; Olejniczak, Wybory, p. 338; Grzegorz Wołk, 'Konfederacja Polski Niepodległej: Studium funkcjonowania opozycyjnej partii politycznej w realiach Polskiej Rzeczypospolitej Ludowej', unpublished doctoral dissertation, Jagiellonian University, 2020, pp. 140-42.

${ }^{50}$ Notatka, 20 March 1965, AAN, KC PZPR, V/79, pp. 371-75; Notatka w sprawie wyborów do Sejmu PRL i rad narodowych w 1969 roku, December 1968, AAN, KC PZPR, V/87, pp. 532-33; Notatka w sprawie działań partyjnych związanych z wyborami do Sejmu PRL, Warsaw, 16 December 1971, AAN, KC PZPR, V/97, p. 828.

${ }^{51}$ Stanisław Nizio in discussion with the author, 26 July 2012, recording in the author's private collection. 
approval by the Central Committee. An analogous procedure was introduced for the so-called allied groupings of the PZPR (the United People's Party and the Alliance of Democrats), whereas candidates from these parties were additionally vetted by the Party itself. ${ }^{52}$

In the 1970s, additional conferences for the submission of candidacies were abandoned. Their function was shifted to regular Party structures in the hope that this would contribute to the "deepening of intra-Party democracy'. ${ }^{53}$ Proposals concerning candidates were made by the executives of provincial committees, and the lists which they drew up were consulted with lower-level Party bodies. An intra-Party instruction provided that no ballots were to be held during such consultative meetings, with only opinions and observations being presented. Possible reservations were to be considered by provincial executives. The decisions which they took were formally accepted by the plenary sessions of provincial committees, and thereafter submitted for final approval at the plenary assembly of the Central Committee; once this was granted, the lists were passed on to the appropriate FJN committees responsible for their registration with electoral commissions. ${ }^{54}$

Although the process of selecting candidates for seats in the Sejm was strongly controlled by the Party authorities, it was always accompanied by a behind-the-scenes rivalry between informal intra-Party factions, cliques, and milieux that wanted their own candidates to be placed on FJN electoral lists. ${ }^{55}$ Whether or not one was included in a list could be decided by a variety of factors, such as one's contacts, the official support of persons occupying specific posts, or having made a name for oneself in political activism. But this concerned primarily the local activists who entered the Sejm as so-called local members, for those higher up in the Party and state hierarchy were placed on electoral lists ex officio, so to speak, as 'central' candidates. In accordance with this principle, in the 1960s and 70s all of

52 Olejniczak, Wybory, pp. 259-60,337-38, 405; Protokół z posiedzenia Wojewódzkiej Komisji Porozumiewawczej Stronnictw Politycznych, 23 November 1960, AP, Białystok (State Archives in Białystok), KW PZPR, 548, p. 11; Protokół nr 1/72 z Plenum KW PZPR w Lublinie, 31 January 1972, AAN, KC PZPR, XII/1224, unpaginated file.

${ }^{53}$ Instrukcja Sekretariatu KC w sprawie trybu wyłaniania kandydatów PZPR na posłów do Sejmu PRL, January 1972, AAN, KC PZPR, VII/33, p. 10.

${ }^{54}$ Ibid., pp. 11-3; W sprawie trybu wyłaniania kandydatów z ramienia PZPR na posłów do Sejmu PRL oraz na radnych do wojewódzkich rad narodowych (Instrukcja Sekretariatu KC), January 1976, AAN, KC PZPR, VII/43, pp. 25-28. This document was included without any modification in materials intended for Party activists during the election campaign of 1980, see AAN, KC PZPR, VII/50, pp. 52-55.

${ }^{55}$ Stanisław Ciosek in discussion with the author, 16 October 2013, recording in the author's private collection. 
the then members of the Political Bureau of the Central Committee of the Polish United Workers' Party became Members of Parliament. ${ }^{56}$

Since it was taken for granted beforehand that all candidates from the 'guaranteed' places on FJN lists would be elected to the Sejm, election campaigns in the Polish People's Republic were never the scenes of heated rivalry. First and foremost, they fulfilled an indoctrinational and activating role, constituting a pretext for intensifying various propaganda actions aimed at mobilizing society for participation in elections and propagating the current 'political line' of the Party and state authorities. From 1965 on, elections to the Sejm were organized in principle a few months after conventions of the Polish United Workers' Party (PZPR), and election campaigns were used for the broad promotion of resolutions and programme documents adopted at these congresses. ${ }^{57}$ The cyclic holding of elections also served to legitimize communist rule. ${ }^{58}$

In successive years, election propaganda followed the established patterns. Emphasis was placed on the manifold achievements of the state authorities, with the period of government of the PZPR being presented as one of Poland's comprehensive development in all fields of social activity. And if official propaganda materials made any mention of difficulties, these were invariably associated with the past. 'We have overcome years of hardship and sacrifice', we read in an electoral appeal of the FJN from 1961. 'We have grappled with a lack of material resources, with the backwardness of technology, with a shortage of trained specialists. Under conditions of great difficulty, we have gained experience of how to work and live anew'. ${ }^{59}$ This was followed by a lengthy enumeration of successes, which was intended to bring home to voters just how apt and attuned to their needs the policies of the ruling communists were. Election campaigns routinely focused on convincing people that socialist Poland had undergone immense social and civilizational development. Another characteristic element of election propa-

${ }^{56}$ Piotr Rowiński, ‘Wybory do Sejmu PRL (1957-1969)', unpublished MA thesis, Warsaw University, 1970, p. 102; Archive of Data on Members of Parliament, <http:// orka.sejm.gov.pl/ArchAll2.nsf > [accessed 3 March 2021].

${ }^{57}$ See, for example, Załącznik nr 3 do posiedzenia Sekretariatu KC PZPR: Plan działalności polityczno-propagandowej w kampanii wyborczej do Sejmu, 21 January 1972, AAN, KC PZPR, VII/33, p. 487; Zadania instancji i organizacji partyjnych w wyborach do Sejmu PRL i rad narodowych stopnia wojewódzkiego. Wytyczne Sekretariatu KC PZPR, January 1980, AP, Szczecin (State Archives in Szczecin), KW PZPR, 2682, p. 87.

${ }^{58}$ For additional information see David Beetham, The Legitimation of Power, Basingstoke and New York, 2013, pp. 179-90.

59 Odezwa wyborcza Ogólnopolskiego Komitetu Frontu Jedności Narodu, February 1961, AAN, KC PZPR, VII/18, p. 12. 
ganda was the myth of the unity of the nation, which was purportedly gathered around the programmes and plans of development charted by the PZPR. Obviously, the reference to the nation as a category was an attempt at garnering nationalistic support for the communist authorities of Poland.$^{60}$ Finally, election propaganda regularly juxtaposed the 'democratic' electoral system of the Polish People's Republic with the alleged infringements of democratic principles in the West. ${ }^{61}$

As for the practical aspects of electioneering in communist Poland, a broad array of tools was employed. Meetings were organized between candidates for Members of Parliament and voters, and these meetings were accompanied by the distribution of official posters and propaganda publications. The Party authorities instructed the press, radio, and television how to cover events, and thereafter analysed in depth whether individual editorial terms were in fact following their guidelines. ${ }^{62}$ The leadership of the PZPR also set its allied groupings and youth organizations certain tasks to perform during campaigns. ${ }^{63}$

An aspect of electioneering that was impossible for the average voter to perceive was the increased activity of the secret political police. Before each election a special staff was organized at the Ministry of Internal Affairs to co-ordinate activities, with identical centres being set up at provincial headquarters of the Citizens' Militia.$^{64}$ Functionaries

${ }^{60}$ For additional information see Zaremba, Komunizm.

${ }^{61}$ See, for example, Robert Stokłosa, 'Wybory do Sejmu PRL w latach 1957-1969 w świetle wrocławskiej prasy’, in Obraz wyborów w prasie XIX i XX wieku na Pomorzu, Śląsku i w Wielkopolsce, ed. Agnieszka Chlebowska and Joanna Nowosielska-Sobel, Szczecin, 2007, pp. 363-79 (p. 375).

${ }^{62}$ Ogólne zasady popularyzacji kandydatów na posłów, 17 April 1969, AAN, KC PZPR, 237/XIX-102, pp. 73-74; Zadania prasy, radia i telewizji w kampanii wyborczej do Sejmu i Wojewódzkich Rad Narodowych, January 1976, AAN, KC PZPR, XXXIII/38, pp. 146-53; Zadania prasy, radia i telewizji po VIII Zjeździe PZPR i przed wyborami do Sejmu i WRN, 26 February 1980, AAN, KC PZPR, XXXIV/138, pp. 172-80; Analiza publicystyki emitowanej w I i II programie TVP w miesiącu lutym 1976 r., March 1976, AAN, KC PZPR, XXXIII/147, pp. 85-100.

${ }^{63}$ Główne kierunki działalności polskiego ruchu młodzieżowego w realizacji uchwały VII Zjazdu PZPR, undated document [January 1976], AAN, KC PZPR, V/134, pp.147-50.

${ }^{64}$ See, for example, Zarządzenie nr 031/61 ministra spraw wewnętrznych w sprawie powołania na okres przedwyborczy i wyborów do Sejmu PRL i Rad Narodowych Sztabu koordynacyjnego w Ministerstwie Spraw Wewnętrznych oraz zadań niektórych służb i jednostek organizacyjnych MSW, 27 February 1961, AIPN, BU 003266/117, pp. 1-3; Regulamin pracy Sztabu MSW (powołanego zarządzeniem nr 09/72 w sprawie kierowania działaniami resortu spraw wewnętrznych w okresie kampanii przedwyborczej oraz wyborów do Sejmu PRL) oraz podziału zadań między poszczególnych członków Sztabu, undated document [January 1972], AIPN, BU 01094/306, pp. 7-8; Zarządzenie nr 042/79 ministra spraw wewnętrznych w sprawie zadań jednostek 
of the Security Service around the country were placed on high alert, and instructed to detect and combat all and any signs of resistance or opposition. The Party authorities were kept abreast of instances of 'anti-state' activity. The security apparatus was particularly interested in those citizens who were expected to display a negative stance, for example, because of their oppositionist behaviour in previous election campaigns. Traditionally, considerable attention was given to the involvement of the Catholic clergy. ${ }^{65}$

The indicators used by the authorities to measure whether an election was successful were turnout and the number of votes cast for candidates occupying 'guaranteed' places on individual regional lists. Official data for elections to the Sejm in the 1960s and 70s show turnouts between $94 \%$ and $99 \%$, with FJN lists always receiving nearly $100 \%$ of votes - all of the candidates allocated 'guaranteed' places invariably won seats. A similarly high numerical participation of voters (again, according to official data) was a characteristic of ballots in all European countries in the Soviet Bloc. From the 1950s until the mid-1980s, the highest turnout (always above 99\%) in every parliamentary election was announced in Bulgaria, Czechoslovakia, and Romania (with a single exception in the latter - 97.9\% - in 1952). The official turnout in the German Democratic Republic was minimally lower, by a fraction of a percentage point. Against this backdrop, Poland and Hungary, with a turnout that sometimes fell under 98\%, came out worst. ${ }^{66}$

Despite the differences, all these numerical data were in fact improbable. Such turnouts are not witnessed even in countries which present reliable election results and where voting is compulsory. ${ }^{67}$ Although voter turnout in European countries in the Soviet sphere of domination was clearly falsified (we will refer to electoral fraud later), the majority of citizens did in fact take part in the ballots and cast their votes in accordance with the guidelines given by the government. Nonetheless, the motivation for voting and the feelings which accompanied the process varied

organizacyjnych resortu spraw wewnętrznych w grudniu 1979 r. i pierwszym kwartale 1980 r., 8 December 1979, AIPN, BU 0296/247, vol. 10, pp. 2-4.

${ }^{65}$ See, for example, Analiza działalności i postawy kleru rzymsko-katolickiego w okresie wyborów do Sejmu i Rad Narodowych w latach 1961 i 1965, June 1965, AIPN, BU 01521/2896, unpaginated file.

${ }^{66}$ Siedziako, Bez wyboru, pp. 44-45, 243.

${ }^{67}$ See, for example, average data on voter turnout for Australia, Belgium, Brazil, and the Republic of the Congo, published on the website: Election Guide: Democracy Assistance \& Elections News, 〈https://www.electionguide.org/countries/id/50/〉 [accessed 19 May 2021]. Cf. Juan J. Linz, 'Non-Competitive Elections in Europe', in Elections Without Choice, pp. 36-65 (p.45). 
considerably. For example, when describing the reasons which led citizens of the German Democratic Republic to vote, Stefan Wolle pointed out the fear of repression, while stressing that abstention did not entail any legal sanctions. In his opinion, Germans did not take the electoral propaganda put out by the communist authorities too seriously, but even so they still voted en masse, sometimes approvingly, although most often with indifference ${ }^{68}$.

The situation was similar in the People's Republic of Poland. People voted in droves under the pressure of propaganda (although it is difficult to determine exactly how many voters actually believed in the slogans) or in fear of the presumed consequences of failure to do so. Typical explanations given for taking part in elections were presented in the samizdat bulletin published by the opposition Committee for Social Self-Defence KOR - namely, the Biuletyn Informacyjny - following the ballot of March 1980. People stated that, for example, they took part in the elections because they had applied for passports or were seeking specialist medical treatment, or hoped their children would get accepted to a better school, or simply wanted to avoid being pestered in their homes by agitators. ${ }^{69}$ The authorities used various means to fuel such anxieties and thus drive people to vote. In the course of a meeting held with first secretaries of provincial committees of the PZPR in April 1961, Władysław Gomułka advised that in order to increase turnout they should attach 'anonymous' annotations to election posters and announcements, worded thus: 'he who does not vote is on the list'. 'Voters will think', he explained his idea to the audience, 'that perhaps this is a reference to a tax list, or to a list of persons earmarked for dismissal from work? Such a tiny typewritten communique could be added here and there, there would be nothing wrong about it'. ${ }^{70}$ Opinions voiced by persons from different milieux in various years and duly noted down by agents of the Security Service, and confirmed by letters (usually anonymous) sent by citizens to the authorities, indicated the widespread conviction that elections were ritualistic in nature. This was accompanied by a deep-rooted certainty that the composition of the Sejm was decided not by voters, but by the Party leadership. ${ }^{71}$

${ }^{68}$ Stefan Wolle, Wspaniały świat dyktatury: Codzienność i władza w NRD 1971-1989, transl. Elżbieta Kaźmierczak and Witold Leder, Warsaw, 2003, pp. 169-70.

69 'Dlaczego głosowałem?', Biuletyn Informacyjny, 36, 1980, 2, pp. 5-6.

${ }^{70}$ Quoted from: Olejniczak, Wybory, p. 166.

${ }^{71}$ For additional information see Michał Siedziako, 'Społeczna percepcja wyborów w PRL w świetle listów nadesłanych do władz podczas konsultacji projektu nowej ordynacji wyborczej do Sejmu w 1985 roku', DN, 50, 2018, 4, pp. 181-200. 
The attainment of the election results desired by the authorities, which could then be presented as a success of the ruling Party, was secured through electoral fraud, although in the 1960s and 70s its scale was much lower than in the 1940s. Extant documentation generated during elections held in the period does, however, contain numerous references to measures taken by members of regional electoral commissions which were analogous to those employed in 1952 and 1957. Although the number of irregularities that were glaringly visible grew smaller and smaller over the years, voting reports still contain references to reclassifications of invalid votes as valid, or reductions of the numbers of persons eligible to vote. It was sometimes the case that the number of eligible persons would be written down in a report in a different hand and using a different ballpoint pen, which allows us to surmise that it was 'calculated' only when the remaining data were known. ${ }^{72}$ Certain reports contain annotations which confirm that voters were pressured by Party activists, such as detailed information about the number of persons who did not vote due to sickness (usually) or because they were away on trips, or how many refused to vote, which means that someone had to persuade them to take part in the ballot. ${ }^{73}$ Another illegal practice that was used to improve turnout consisted in allowing one voter to cast a number of votes - for example, on behalf of family members or neighbours. ${ }^{74}$ Years later, the

72 See, for example, Protokół głosowania na posłów w okręgu nr 1 w obwodzie 179, 23 March 1980, AKPRP, KRP, file without signature titled: 'Materiały terenowe. Protokoły głosowania obwodowych komisji wyborczych. Okręg nr 1 - Warszawa-Śródmieście', unpaginated; Protokół głosowania na posłów w obwodzie nr 176 w okręgu wyborczym nr 2, 21 March 1976, AKPRP, KRP, file without signature titled: 'Materiały terenowe. Protokoły głosowania okręgowych i obwodowych komisji wyborczych. Okręg nr 2 - woj. st. warszawskie', p. 8; Protokół głosowania sporządzony przez Obwodową Komisję Wyborczą nr 13 w okręgu wyborczym nr 15, 16 April 1961, AAN, PKW, 452, pp. 168-69; Protokół głosowania sporządzony przez Obwodową Komisję Wyborczą nr 39 w okręgu wyborczym nr 26, 17 April 1961, AAN, PKW, 463, pp. 80-81. For additional information see Siedziako, Bez wyboru, pp. 254-55.

${ }^{73}$ See, for example, Protokół głosowania sporządzony przez Obwodową Komisję Wyborczą nr 1 w okręgu wyborczym nr 15,16 April 1961, AAN,PKW, 452,pp. 284-85; Protokół głosowania sporządzony przez Obwodową Komisję Wyborczą nr 150 w okręgu wyborczym nr 1, 19 March 1972, AKPRP, KRP, file without signature titled: 'Protokoły głosowania okręgowej i obwodowych komisji wyborczych, Okręg nr 1-m. st. Warszawa', unpaginated.

${ }^{74}$ See, for example, List Michała Niesyna do Przewodniczącego Rady Państwa prof. Henryka Jabłońskiego, 24 March 1980, AKPRP, KRP, file without signature titled: 'Skargi i wnioski związane z wyborami do Sejmu PRL i rad narodowych st. wojewódzkiego, 1980 r.', unpaginated; List Zygmunta Melasy do Kancelarii Rady Państwa, 9 January 1985, AKPRP, KRP, file without signature titled: 'Opinie indywidualne dot. "Założeń do projektu ustawy Ordynacja wyborcza do Sejmu PRL”, 1985 r., teczka 1', unpaginated. 
utilization of such practices was mentioned in direct interviews with former members of regional electoral commissions. ${ }^{75}$

The results of ballots arrived at through such methods clearly did not reflect the actual electoral behaviour of citizens, all the more so as the possibility of actually making a choice was blocked administratively through the registration of only one electoral list. Nonetheless, the specific methods used to falsify election results make it practically impossible to recreate the actual outcomes of these ballots.

An Unsuccessful Attempt at Reform and the Last Elections in the Polish People's Republic

The last elections to the Sejm that were conducted in accordance with the models outlined above took place in March 1980. A few months later, Poland became enveloped in a manifold crisis brought on by the country's catastrophic economic situation, which was felt by citizens from all walks of life with ever more acuteness. The riots of the summer of 1980, which erupted in response to the increase in food prices introduced by the authorities, led to the emergence of an enormous democratic social movement centred round the Independent Self-Governing Trade Union 'Solidarity', which over time gained approximately ten million members in a country with an entire population of some thirty-five million. This was a development without precedence in the Soviet Bloc. The appearance on the public stage of such a significant actor independent of the Party was a blow to the very core of the political system of the People's Republic of Poland. The ruling PZPR experienced a considerable weakening of support and its ranks started melting away; worse still, decentralist tendencies reared their heads - so much so that the leadership started discussing the possible dissolution of the Party and its replacement with a completely new grouping. This turn of events strengthened the position of the armed forces and ultimately led to the introduction of martial law on 13 December 1981. Over the next few years, supreme power in the country was exercised by General Wojciech Jaruzelski, who gathered in his hands all the key Party and state positions, including that of First Secretary of the Central Committee of the PZPR (1981-89), Prime Minister (1981-85), and Chairman of the Council of State (1985-89). As the de facto head of the Polish People's Republic,

${ }^{75}$ Marian Szefler in discussion with the author, 24 November 2014; Andrzej Sawicki in discussion with the author, 19 September 2017, recordings in the author's private collection. 
General Jaruzelski based himself on the weakened Party structures only to a limited extent; far greater use was made of the security apparatus and the army, and of an informal group of arbitrarily selected advisors. ${ }^{76}$

Throughout the 1980s, the authorities were faced with three fundamental problems: alleviating the country's tragic economic situation, limiting the influence of the opposition, and restoring their own position and standing. The suspension of martial law in 1983 allowed them to regain control of the situation only in part, for even though they announced 'normalization', the crisis of the state was far from over. ${ }^{77}$ Under the constitution, elections were due to be held in the spring of 1984, but in the circumstances, it was decided to postpone them by over a year, obviously so as not to risk losing control over the composition of parliament under such perilous conditions. However, the legitimacy of the Party and state authorities, dangerously eroded, was to be revived by the organization of elections in accordance with new principles. Just as in the mid-1950s, the stated objective of the planned reforms was 'democratization'. In 1985, a fresh electoral statute was adopted. Amongst its most important changes was the requirement that at least two candidates had to stand for one parliamentary seat. Furthermore, it established new intra-Party rules for selecting candidates for MPs, among others providing for the appointment of special electoral conventions that were to co-participate in the selection process with Party committees. ${ }^{78}$ Another novelty was the replacement of the Front of National Unity (FJN) with the Patriotic Front of National Rebirth (PRON being the Polish acronym). According to state propaganda, PRON was a grass-roots movement; in reality, however, it was just another Party-controlled organization and served the same purpose as the FJN.

These changes in the electoral system could hardly be called a reform, however. Yet again the elections were organized by making use of tried and trusted practices that allowed the PZPR to control the whole process; Party bodies continued to decide the composition of all institutions and organizations involved in the elections, only lists of the PRON could be registered, votes 'without crossings-out' were still permitted, and 'guaranteed' and 'non-guaranteed' places were maintained on elec-

${ }^{76}$ For additional information on the system of government under General Jaruzelski see Paweł Kowal, Koniec systemu władzy: Polityka ekipy gen. Wojciecha Jaruzelskiego w latach 1986-1989, Warsaw, 2012.

77 See Jacques Rupnik, ‘The Military and "Normalisation” in Poland', in Eastern Europe: Political Crisis and Legitimation, ed. Paul G. Lewis, London and Sydney, 1984, pp. 154-75.

78 'Regulamin wyłaniania kandydatów na posłów do Sejmu PRL z ramienia PZPR', 12-13 June 1985, in Uchwały Komitetu Centralnego Polskiej Zjednoczonej Partii Robotniczej od IX do X Zjazdu, Warsaw, 1986, pp. 949-50. 
toral lists. Before being placed on a list, all candidates were vetted by the Party and functionaries of the Security Service. ${ }^{79}$ In essence, therefore, the Party leadership had already determined the political composition of the Sejm in May 1985, whereas the ballot was not held until October. $^{80}$

The elections to the 1985 Sejm were, however, different from those previously held in the Polish People's Republic for two fundamental reasons. First of all, although 'Solidarity' and other independent organizations had been banned under martial law, the authorities had proved unable to eliminate the political opposition altogether, and it continued to thrive underground. Oppositionists were not allowed to run for seats in parliament, but their activities were nevertheless a visible element of the election campaign and served to disturb the uniform image presented by state propaganda. They argued that the elections to the Sejm were a contradiction of democracy, and called upon the population not to vote. Furthermore, the opposition organized independent monitoring of the course of voting.

Secondly, the sheer impact of the opposition's existence caused the authorities - afraid of the broad exposure of violations of electoral law - to refrain from using illegal methods to improve turnout on the previous scale. This made it impossible to yet again report a turnout of nearly $100 \%$. According to the official announcement of the State Electoral Commission, just under 79\% eligible voters took part in 1985, while independent observers declared that the percentage was even lower, totalling approximately $66 \%{ }^{81}$ Although all of the candidates from 'guaranteed' places again won seats, the visible activity of the political opposition made it difficult for the authorities to proclaim slogans of 'national unity', and such a low turnout obviously did not serve to increase the legitimacy of the ruling PZPR. But this was just a foretaste of the crushing electoral defeat that befell the Party in the last elections to the Sejm of the Polish People's Republic, the so-called contractual elections, which were arranged by representatives of the authorities and the moderate wing of the opposition during the Round Table Talks in the spring of 1989.

${ }^{79}$ Antoni Dudek, Reglamentowana rewolucja: Rozkład dyktatury komunistycznej w Polsce 1988-1990, Cracow, 2014, p. 62; Załącznik do informacji dziennej dot. wyborów do Sejmu PRL - działania resortu spraw wewnętrznych, 2 December 1985, AIPN, BU 0236/301, vol. 2, p. 399.

${ }^{80}$ Informacja o zasadach kształtowania składu politycznego i społeczno-zawodowego Sejmu PRL, 28 May 1985, AAN, KC PZPR, V/266, pp. 21, 23.

81 'Komunikat Konrada Bielińskiego, pełnomocnika Tymczasowej Komisji Koordynacyjnej NSZZ "Solidarność” do spraw pomiaru frekwencji wyborczej', 16 October 1985, in Dokumenty władz NSZZ 'Solidarność' 1981-1989, ed. Jan Olaszek, Warsaw, 2010, pp. 211-13. 
The agreement signed in consequence of the Round Table negotiations provided that $65 \%$ of seats in the new Sejm would be held by the PZPR and its co-operating entities (the 'Party and government camp'), while the other $35 \%$, and the entirety of seats in the Senate - which was to be restored - would be freely contested by all candidates. ${ }^{82}$

The campaign preceding the elections, which were fixed for 4 and 18 June 1989 (the majority electoral system called for two rounds of voting), was to be 'non-confrontational'. But in the political realities of the time, with two diametrically opposed political camps vying for votes, such an arrangement was completely unrealistic. The approach of the Party and government camp was firmly based on the historical model. Meetings of candidates for parliament with voters lacked energy, and, as in previous years, they were staged, with long, boring speeches read from notes. As for the seats that could be contested, the key error committed by the authorities was that they allowed more than one candidate to stand for each seat. This resulted in support for the ruling camp being scattered between many nominees. ${ }^{83}$

Their opponents, however, working under the aegis of the 'Solidarity' Citizens' Committee, put forward only one candidate for each seat in both the Sejm and Senate ${ }^{84}$ thereby avoiding the dispersion of votes. Furthermore, 'Wałęsa's team' created an image of unity and cohesion, which helped increase electoral support. Although this projection was not actually true, its promotion paid dividends: ${ }^{85}$ the opposition was able to distinguish itself from the crumbling government camp even more effectively. A symbolic example of the practical application of this strategy is that of the posters and leaflets showing opposition nominees shaking the hand of the instantly recognizable chairman of 'Solidarity'. Thus, although the majority of these candidates were not well known to the public, photographs with Wałęsa facilitated their political identification. ${ }^{86}$ The electoral meetings organized by 'Solidarity' were professional political shows, and many were graced by famous artists and people of culture, among them Jane Fonda and Stevie Wonder. When describing the

82 'Stanowisko w sprawie reform politycznych', 5 April 1989, in Okragły Stót, ed. Krzysztof Dubiński, Warsaw, 1999, pp. 555-56.

${ }^{83}$ Codogni, Wybory, p. 194.

${ }^{84}$ For additional information see Inka Słodkowska, Komitety Obywatelskie 1989-1992: Rdzeń polskiej transformacji, Warsaw, 2014, pp. 35-111.

${ }^{85}$ Dudek, Reglamentowana rewolucja, p. 256.

${ }^{86}$ For additional information see Adam Cherek, 'Przyczyna zwycięstwa?: Historia plakatów wyborczych Komitetu Obywatelskiego "Solidarność” z Lechem Wałęsą', in Krok ku wolności: Wybory czerwcowe 1989 i ich konsekwencje, ed. Konrad Białecki, Stanisław Jankowiak and Rafał Reczek, Poznań, 2015, pp.317-31. 
electoral campaign of the 'Solidarity' Citizens' Committee, we cannot fail to mention the moral support provided by the clergy of the Catholic Church. ${ }^{87}$

On 4 June 1989, candidates put forward by the Citizens' Committee took 160 of the 161 contested seats in the lower house and 92 seats in the Senate - a resounding and thorough victory. The last seat in the Sejm and eight of the nine remaining seats in the Senate were won as a result of the second round of voting. Although the pre-agreed division of seats meant that the PZPR and its allies were guaranteed a numerical advantage, its candidates failed to win even one of the contested seats. Voters had clearly shown that they no longer wanted it in power. This was the first step towards the peaceful dismantlement of the communist dictatorship in Poland. ${ }^{88}$

\section{Conclusions}

Parliamentary elections held in Poland during the period of communist rule were based on procedures that bore only an outward resemblance to those applied in democratic countries. In the Polish People's Republic, voters had no opportunity to choose between representatives of different political options, and their participation in elections boiled down to voting for candidates who had already been selected and approved by the governing Polish United Workers' Party. Through its control over the staffing of the electoral apparatus, the selection of candidates for Members of Parliament, pressuring voters, and, finally, electoral fraud, the Party assured itself complete command over the make-up of the Polish Sejm from the first year of its functioning - 1952 - until 1985. The electoral practices used in Poland in this period originated in the Soviet Union, however they were not a simple carbon copy. The electoral system of the People's Republic of Poland was shaped during the first four post-war ballots, and was thereafter used until 1980 with only cosmetic modifications. The 1980s witnessed the destabilization of communist rule in Poland, a clear manifestation of which were, among others, the elections to the Sejm of 1985. Although at the time the PZPR retained its control over the composition of parliament, the very presence of an active opposition movement made it impossible to copy the previous

${ }^{87}$ Codogni, Wybory, pp. 167; Krzysztof Koseła, ‘Rola Kościoła katolickiego w kampanii przed wyborami czerwcowymi', in Wyniki badań - wyniki wyborów 4 czerwca 1989, ed. Lena Kolarska-Bobińska, Piotr Łukasiewicz and Zbysław W. Rykowski, Warsaw, 1990, pp. 95-142.

${ }^{88}$ For additional information see Siedziako, Bez wyboru, pp. 333-46. 
electoral model, which envisaged an official turnout of nearly $100 \%$ and widespread approval for candidates put forward by the authorities. When in 1989 Polish voters were granted the possibility of making an effective choice, the ruling camp lost in a comprehensive defeat that opened the way to further democratic change in the country. The ballot of June $1989-$ the first 'elections' in the proper meaning of the word to be held in Poland after the Second World War - was followed in rapid succession by elections to the restored territorial self-government (May 1990) and to a fully democratic parliament (October 1991).

Ballots in the People's Republic of Poland may be viewed as an example of how electoral procedures functioned in the whole Soviet Bloc. The guiding principle of the political systems of those states was that of one-party rule, to which there was no alternative in the sense of entities functioning on the political scene legally and representing different political options. In essence, communist rule was not intended to be assessed and verified by citizens/voters, and was not subject to the democratic turnover of power. Under such conditions the cyclical organization of elections to bodies of representative government could be deemed pointless. Nevertheless, the communists, although there was no alternative to their rule in the countries of real socialism, even where they officially had multi-party systems, as in Poland, the German Democratic Republic, and Czechoslovakia, did regularly hold elections. Indeed, elections to representative institutions and the preceding electoral campaigns constituted an important element in the calendar of political events organized by the communist authorities, in addition to commemorations of various state holidays or successive anniversaries of the Bolshevik Revolution of 1917. But although they were based on procedures that at first glance appeared similar to those applied in democratic countries, these were governed by a completely different set of rules, fulfilled distinct functions, and had a disparate significance. This fact is worth keeping in mind, particularly as in both instances - in the countries of the former Eastern Bloc and in those of the West - use was made of the same term: elections. However, its practical definition differed markedly. 


\section{Summary}

In all countries of the Soviet Bloc, even though they were ruled with absolute power by the communists, whose governance citizens could not assess or change, parliamentary elections were a regular occurrence. Although seemingly held just like elections in democratic countries, they served a completely different function, for they did not allow voters to choose their representatives. Rather, they constituted a pretext for the organization of propaganda campaigns, the mobilization of citizens in active support of the authorities, and the provision of apparent legitimacy to the government. Typical elections of this type were those to the Sejm in communist-ruled Poland. The article outlines the development of the electoral system of the Polish People's Republic and the main features of its mature phase. It contains a detailed description of the following aspects: control over the electoral apparatus and the selection of candidates for Members of Parliament by the Polish United Workers' Party, the organization of election campaigns and electoral propaganda, actions aimed at pressuring voters into certain forms of behaviour, and electoral fraud. In the final part of his text the author discusses the unsuccessful reform of the parliamentary electoral system in 1985 and the collapse of the model of uncontested elections in Poland in the 1980s, which contributed to the disintegration of the communist dictatorship.

(Translated by Maciej Zakrzewski)

\section{Bibliography}

\section{Archives}

Archives of Modern Records:

- Office of the All-Polish Committee of the National Front;

- Central Committee of the Polish United Workers' Party;

- State Electoral Commission;

- Elections to the Sejm of 1952 - collection of files.

Archive of the Institute of National Remembrance.

State Archives in Białystok:

- Provincial Committee of the Polish United Workers' Party.

State Archives in Lublin:

- Provincial Committee of the Polish United Workers' Party.

State Archives in Szczecin:

- Provincial Committee of the Polish United Workers' Party.

Archive of the Chancellery of the President of the Republic of Poland:

- Chancellery of the Council of State. 


\section{Accounts}

Ciosek, Stanisław, in discussion with the author, 16 October 2013, recording in the author's private collection.

Nizio, Stanisław, in discussion with the author, 26 July 2012, recording in the author's private collection.

Sawicki, Andrzej, in discussion with the author, 19 September 2017, recording in the author's private collection.

Szefler, Marian, in discussion with the author, 24 November 2014, recording in the author's private collection.

\section{Press publications}

'Dlaczego głosowałem?', Biuletyn Informacyjny, 36, 1980, 2, pp. 5-6.

\section{Printed sources}

'Ogłoszenie Generalnego Komisarza Głosowania Ludowego o wyniku głosowania ludowego z dnia 30 czerwca 1946 r.', Monitor Polski, 12 July 1946, no. 61, item 115.

\section{Unpublished works}

Popiela, Tomasz, 'Nowy Sącz w latach eksperymentu sądeckiego 1958-1964', unpublished MA thesis, Jagiellonian University, 2014.

Rowiński, Piotr, 'Wybory do Sejmu PRL (1957-1969)', unpublished MA thesis, Warsaw University, 1970.

Wołk, Grzegorz, ‘Konfederacja Polski Niepodległej: Studium funkcjonowania opozycyjnej partii politycznej w realiach Polskiej Rzeczypospolitej Ludowej', unpublished doctoral dissertation, Jagiellonian University, 2020.

\section{Literature}

Barany, Zoltan D., 'Elections in Hungary', in Elections in Socialist States, ed. Robert K. Furtak, New York: St. Martin's Press, 1990, pp. 71-97.

Beetham, David, The Legitimation of Power, Basingstoke and New York: Palgrave Macmillan, 2013.

Brunner, Georg, 'Elections in the Soviet Union', in Elections in Socialist States, ed. Robert K. Furtak, New York: St. Martin's Press, 1990, pp. 20-52.

Cherek, Adam, 'Przyczyna zwycięstwa?: Historia plakatów wyborczych Komitetu Obywatelskiego "Solidarność” z Lechem Wałęsą', in Krok ku wolności: Wybory czerwcowe 1989 i ich konsekwencje, ed. Konrad Białecki, Stanisław Jankowiak and Rafał Reczek, Poznań: Instytut Pamięci Narodowej; Uniwersytet Adama Mickiewicza, 2015, pp. 317-31.

Churska-Wołoszczak, Kamila, Referendum ludowe i wybory do Sejmu Ustawodawczego w województwie pomorskim (1946-1947), Bydgoszcz and Gdańsk: Instytut Pamięci Narodowej, 2014.

Codogni, Paulina, Wybory czerwcowe 1989 r.: U progu przemiany ustrojowej, Warsaw: Instytut Pamięci Narodowej, 2012. 
Dąbrowska, Maria, Dzienniki: 1914-1965, 13 vols, Warsaw: Polska Akademia Nauk, Wydział I Nauk Społecznych, Komitet Nauk o Literaturze, 2009, vol. 10.

Danilecki, Tomasz, Między zaangażowaniem, przystosowaniem i sprzeciwem: Postawy mieszkańców województwa białostockiego wobec wyborów powszechnych w latach 1957-1969, Białystok and Warsaw: Instytut Pamięci Narodowej, 2019.

Dokumenty władz NSZZ 'Solidarność' 1981-1989, ed. Jan Olaszek, Warsaw: Instytut Pamięci Narodowej, 2010.

Drygalski, Jerzy, and Jacek Kwaśniewski, 'No-Choice Elections', Soviet Studies, 42, 1990, 2, pp. 295-315.

Dudek, Antoni, Reglamentowana rewolucja: Rozkład dyktatury komunistycznej w Polsce 1988-1990, Cracow: Wydawnictwo Znak, 2014.

Eisler, Jerzy, The 'Polish Months': Communist-ruled Poland in Crisis, transl. Jerzy Giebułtowski, Warsaw: Instytut Pamięci Narodowej, 2019.

Elections in Europe: A Data Handbook, ed. Dieter Nohlen and Philip Stöver, Baden-Baden: Nomos, 2010.

Elections in Socialist States, ed. Robert K. Furtak, New York: St. Martin's Press, 1990. Elections Without Choice, ed. Guy Hermet, Richard Rose and Alain Rouquié, London and Basingstoke: The Macmillan Press Ltd, 1978.

Friedgut, Theodore H., Political Participation in the USSR, Princeton, NJ: Princeton University Press, 1979.

Giurescu, Dinu C., Fakers: The 1946 Elections, transl. Adriana Cerkez, Boulder, CO: East European Monographs, 2009.

Glaessner, Gert-Joachim, 'Elections in the German Democratic Republic', in Elections in Socialist States, ed. Robert K. Furtak, New York: St. Martin's Press, 1990, pp. 53-70.

Heumos, Peter, 'Works Council Elections in Czechoslovakia, 1948-1968', Voting for Hitler and Stalin: Elections under $20^{\text {th }}$ Century Dictatorships, ed. Ralph Jessen and Hedwig Richter, Frankfurt am Main: Campus Verlag, 2011, pp. 186-203.

Kersten, Krystyna, Narodziny systemu władzy: Polska 1944-1948, Warsaw: Instytut Studiów Politycznych Polskiej Akademii Nauk; Fundacja Kerstenów; Textura Jerzy Giebułtowski, 2018.

Koseła, Krzysztof, 'Rola Kościoła katolickiego w kampanii przed wyborami czerwcowymi', in Wyniki badań - wyniki wyborów 4 czerwca 1989, ed. Lena Kolarska-Bobińska, Piotr Łukasiewicz and Zbysław W. Rykowski, Warsaw: Ośrodek Badań Społecznych, 1990, pp. 95-142.

Koseski, Adam, 'Walka o władzę w Bułgarii', in Czy Europa Środkowo-Wschodnia mogła wybić się na wolność?, ed. Tadeusz Kisielewski and Norbert Kasparek, Olsztyn: Wyższa Szkoła Pedagogiczna, 1996, pp. 123-45.

Kowal, Paweł, Koniec systemu władzy: Polityka ekipy gen. Wojciecha Jaruzelskiego w latach 1986-1989, Warsaw: Instytut Studiów Politycznych Polskiej Akademii Nauk; Instytut Pamięci Narodowej; Wydawnictwo Trio, 2012.

Lebeda, Tomáš, 'Czech Republic', in Elections in Europe: A Data Handbook, ed. Dieter Nohlen and Philip Stöver, Baden-Baden: Nomos, 2010, pp. 453-500. 
Lindner, Ralf, and Rainer-Olaf Schultze, 'Germany', in Elections in Europe: A Data Handbook, ed. Dieter Nohlen and Philip Stöver, Baden-Baden: Nomos, 2010, pp.723-806.

Linz, Juan J., 'Non-Competitive Elections in Europe', in Elections Without Choice, ed. Guy Hermet, Richard Rose and Alain Rouquié, London and Basingstoke: The Macmillan Press Ltd, 1978, pp. 36-65.

Machcewicz, Paweł, Rebellious Satellite: Poland 1956, transl. Maya Latynski, Washington, DC: Woodrow Wilson Center Press; Stanford, CA: Stanford University Press, 2009.

Machcewicz, Paweł, 'Wstęp', in Kampania wyborcza i wybory do Sejmu 20 stycznia 1957, ed. Paweł Machcewicz, Warsaw: Wydawnictwo Sejmowe, 2000.

Merl, Stephan, 'Elections in the Soviet Union, 1937-1989: A View into a Paternalistic World from Below', in Voting for Hitler and Stalin: Elections under $20^{\text {th }} \mathrm{Cen}$ tury Dictatorships, ed. Ralph Jessen and Hedwig Richter, Frankfurt am Main: Campus Verlag, 2011, pp. 276-308.

Mote, Max E., Soviet Local and Republic Elections: A Description of the 1963 Elections in Leningrad Based on Official Documents, Press Accounts, and Private Interviews, Stanford, CA: The Hoover Institution on War, Revolution, and Peace, 1965.

Motyka, Grzegorz, Na białych Polaków obława: Wojska NKWD w walce z polskim podziemiem 1944-1953, Cracow: Wydawnictwo Literackie, 2014.

Okragły Stół, ed. Krzysztof Dubiński, Warsaw: Krajowa Agencja Promocyjna, 1999.

Olejniczak, Joanna, Wybory do Sejmu i rad narodowych w województwie bydgoskim w okresie tzw. małej stabilizacji (1956-1970), Toruń: Wydawnictwo Adam Marszałek, 2010.

Osękowski, Czesław, Referendum 30 czerwca 1946 roku w Polsce, Warsaw: Wydawnictwo Sejmowe, 2000.

Osękowski, Czesław, Wybory do sejmu 19 stycznia 1947 roku w Polsce, Poznań: Wydawnictwo Poznańskie, 2000.

Petrov, Nikita, 'Sztuka wygrywania wyborów', Karta, 18, 1996, pp. 121-29.

Pravda, Alex, 'Elections in Communist Party States', in Communist Politics: A Reader, ed. Stephen White and Daniel Nelson, Basingstoke and London: Macmillan Education Ltd, 1986, pp. 27-54.

Problemy frontu narodowego w europejskich państwach socjalistycznych, ed. Marian Rybicki, Wrocław: Zakład Narodowy im. Ossolińskich, 1973.

Referendum z 30 czerwca 1946 r.: Przebieg i wyniki, ed. Andrzej Paczkowski, Warsaw: Instytut Studiów Politycznych Polskiej Akademii Nauk, 1993.

Richter, Hedwig, 'Mass Obedience: Practices and Functions of Elections in the German Democratic Republic', Voting for Hitler and Stalin: Elections under $20^{\text {th }}$ Century Dictatorships, ed. Ralph Jessen and Hedwig Richter, Frankfurt am Main: Campus Verlag, 2011, pp. 103-25.

Romanow, Zenon, Demokracja ludowa w praktyce: Wybory do Sejmu i rad narodowych $w$ województwie koszalińskim w latach 1950-1975, Słupsk: Wydawnictwo Akademii Pomorskiej, 2019. 
Rupnik, Jacques, 'The Military and 'Normalisation' in Poland', in Eastern Europe: Political Crisis and Legitimation, ed. Paul G. Lewis, London and Sydney: Croom Helm, 1984, pp. 154-75.

Siedziako, Michał, Bez wyboru: Głosowania do Sejmu PRL (1952-1989), Warsaw: Instytut Pamięci Narodowej, 2018.

Siedziako, Michał, 'Manipulacje i fałszerstwa wyborcze w wyborach do Sejmu PRL (1952-1985)', Pamięć i Sprawiedliwość, 27, 2016, 1, pp. 112-39.

Siedziako, Michał, 'Przygotowanie wyborów do Sejmu PRL I kadencji w 1952 roku jako element procesu sowietyzacji Polski po II wojnie światowej', Zeszyty Naukowe Uniwersytetu Jagiellońskiego. Prace Historyczne, 144, 2017, 4, pp. 739-58.

Siedziako, Michał, 'Społeczna percepcja wyborów w PRL w świetle listów nadesłanych do władz podczas konsultacji projektu nowej ordynacji wyborczej do Sejmu w 1985 roku', DN, 50, 2018, 4, pp. 181-200.

Skobelski, Robert, 'Controversies Surrounding the Selection of Candidates for MPs Before the Election to the PRL Sejm of January 1957', Res Historica, 49, 2020, pp. 425-64.

Skobelski, Robert, 'Ostatnia odsłona odwilży: Kampania przed wyborami do Sejmu PRL ze stycznia 1957 roku', Pamięć i Sprawiedliwość, 35, 2020, 1, pp. 402-35.

Skorut, Paweł, Front Jedności Narodu: Od narodzin idei do upadku politycznego pozoru, Cracow: Attyka, 2015.

Słodkowska, Inka, Komitety Obywatelskie 1989-1992: Rdzeń polskiej transformacji, Warsaw: Instytut Studiów Politycznych Polskiej Akademii Nauk, 2014.

Sokół, Wojciech, 'Systemy wyborcze w Polsce Ludowej - uwarunkowania, mechanizmy i konsekwencje polityczne', in Wybory i referenda w PRL, ed. Sebastian Ligarski and Michał Siedziako, Szczecin: Instytut Pamięci Narodowej, 2014, pp. 23-44.

Stokłosa, Robert, 'Wybory do Sejmu PRL w latach 1957-1969 w świetle wrocławskiej prasy', in Obraz wyborów w prasie XIX i XX wieku na Pomorzu, Ślasku i w Wielkopolsce, ed. Agnieszka Chlebowska and Joanna Nowosielska-Sobel, Szczecin: Wydawnictwo Uniwersytetu Szczecińskiego, 2007, pp. 363-79.

Szymczak, Tadeusz, Ustrój europejskich państw socjalistycznych, Warsaw: Państwowe Wydawnictwo Naukowe, 1988.

Uchwały Komitetu Centralnego Polskiej Zjednoczonej Partii Robotniczej od IX do X Zjazdu, Warsaw: Książka i Wiedza, 1986.

Voting for Hitler and Stalin: Elections under $20^{\text {th }}$ Century Dictatorships, ed. Ralph Jessen and Hedwig Richter, Frankfurt am Main: Campus Verlag, 2011.

Wojsław, Jacek, 'Kampania propagandowa towarzysząca wyborom do Sejmu z 26 października 1952 roku', Polska 1944/45-1989: Studia i Materiały, 9, 2010, pp.133-53. Wolle, Stefan, Wspaniały świat dyktatury: Codzienność i władza w NRD 1971-1989, transl. Elżbieta Kaźmierczak and Witold Leder, Warsaw: Wiedza Powszechna, 2003.

Wrona, Janusz, 'Wstęp', in Kampania wyborcza i wybory do Sejmu Ustawodawczego 19 stycznia 1947, ed. Janusz Wrona, Warsaw: Wydawnictwo Sejmowe, 1999. 
Wybory i referenda $w$ PRL, ed. Sebastian Ligarski and Michał Siedziako, Szczecin: Instytut Pamięci Narodowej, 2014.

Zaćmiński, Andrzej, Kampania wyborcza i wybory do Sejmu PRL I kadencji z 1952 r.: Studium totalitarnej elekcji parlamentarnej, Bydgoszcz: Wydawnictwo Uniwersytetu Kazimierza Wielkiego, 2020.

Zaćmiński, Andrzej, 'Poezja agitacyjna w kampanii wyborczej do Sejmu PRL pierwszej kadencji z 26 października 1952 r.: Tematyka - Obrazowanie - Polityka', DN, 50, 2018, 2, pp. 181-214.

Zaremba, Marcin, Komunizm, legitymizacja, nacjonalizm: Nacjonalistyczna legitymizacja władzy komunistycznej w Polsce, Warsaw: Wydawnictwo Trio, 2005.

Zawadzka, Barbara, Model przedstawicielstwa socjalistycznego: Studium porównawcze z teorii reprezentacji, Wrocław: Zakład Narodowy im. Ossolińskich; Wydawnictwo Polskiej Akademii Nauk, 1980.

\section{Internet}

Archive of Data on Members of Parliament, 〈http://orka.sejm.gov.pl/ArchAll2 .nsf $>$ [accessed 3 March 2021].

Election Guide: Democracy Assistance \& Elections News, <https://www .electionguide.org/countries/id/50/ $>$ [accessed 19 May 2021]

Biography: Dr Michał Siedziako - political scientist and historian, is a chief specialist at the Departmental Office for Historical Research of the Institute of National Remembrance in Szczecin and an assistant professor at the Institute of Political Science and Security Studies of the University of Szczecin. His research interests focus on the political history of Poland under communist rule. E-mail: msiedziako@wp.pl. 